\title{
INTRUZ W STARYM ATELIER, CZYLI CO NAM DZISIAJ PO TAMTYCH FOTOGRAFIACH (PRÓBA FOTOESEJU*)
}

BRYGIDA PAWŁOWSKA-JĄDRZYK Wydział Nauk Humanistycznych Uniwersytetu Kardynała Stefana Wyszyńskiego; Faculty of Humanities Cardinal Stefan Wyszyński University in Warsaw (Poland) brygida.pawlowska@gmail.com

Roland Barthes określa Fotografię jako sztukę „niezbyt pewną”, skazującą poniekąd własnych admiratorów na wygłaszanie spostrzeżeń bezładnych, przypadkowych i niejasnych ${ }^{1}$. Jakkolwiek może się to wydać decyzją paradoksalną, autor Światła obrazu, zmierzając do uzasadnienia swoich subiektywnych wrażeń zrodzonych z obcowania z tą sztuką, postanawia wyjść od upodobania, z jakim ogląda niektóre zdjęcia. Takie intuicyjne podejście narzuca się chyba każdemu, komu naprawdę zdarzyło się głęboko przeżyć jakąś fotografię. Trudno nie zapytać w tym kontekście: czym jest ta szczególna reakcja na dane zdjęcie, która przytrafia się ludziom o pewnym rodzaju wrażliwości, a dla innych, być może, musi pozostać niezrozumiała czy wręcz osobliwa? - Ekscytacją? Jakimś rodzajem iluminacji? A może po prostu zdumieniem? - Osobiście najpełniej identyfikuję się z następującymi słowami: to, co we mnie wywołuje fotografia, którą szczególnie lubię i wyróżniam, to ,(...) podniecenie wewnętrzne, święto, a także oddziaływanie, nacisk czegoś niewyrażalnego, co chce się wypowiedzieć (...)”2.

\footnotetext{
${ }^{1}$ R. Barthes, Światto obrazu. Uwagi o fotografii, thum. J. Trznadel, Warszawa 2008, s. 34.

${ }^{2}$ Tamże, s. 37-38.
} 


\section{I.}

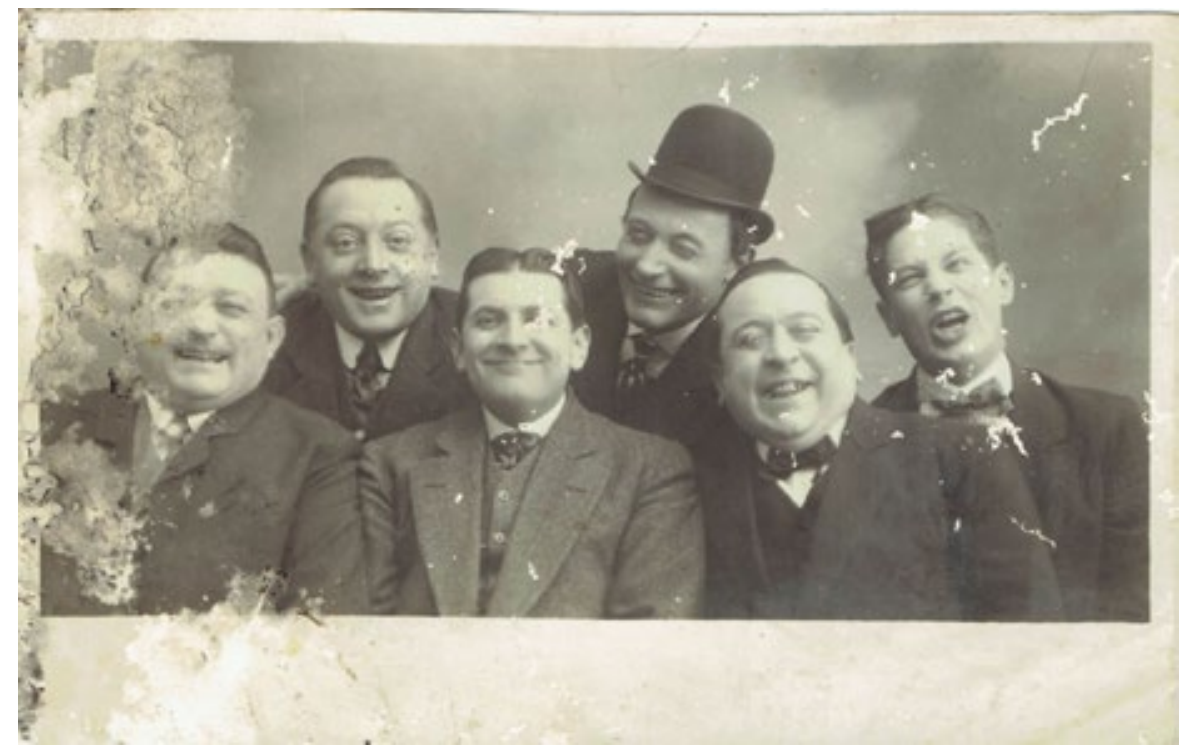

Fotografia nr 1

Lękam się mówić o tej fotografii. Lękam się, bo budzi we mnie przejmujące uczucia. Ale i osobliwą otuchę... Jak mam przekazać to, co odczuwam, gdy twardo trzymam ją w dłoni, tym, którzy widzą ją na ekranie komputera i składają swe emocje $\mathrm{z}$ wiązek migoczących pikseli? Nasze doznania nie mogą się spotkać, choć przecież istniejemy w tej samej epoce, mówimy tym samym językiem. Dzieje się tak zapewne dlatego, że p r a w d z i w a fo to grafia jest także przedmiotem, a przynajmniej-jakkolwiek zabrzmi to dziwnie - przedmiotem „się staje”: z upływem czasu n a b i e r a w a g i , między innymi (przede wszystkim?) dzięki swej materialnej naturze. Po upływie wielu lat zaczyna „doskwierać”, ciążyć balastem linii papilarnych, zatopionych niegdyś w matowej powierzchni, a może i śladami potu tych, którzy teraz wpatrują się w nas idealnie nieruchomym spojrzeniem. 
Czasem jeszcze wplątuje nasze emocje w zawijasy niezwykłego pisma, do jakiego dziś już nie jest zdolna żadna ręka, jak w przypadku tej pamiątki po warszawskich wojażach przybysza z ojczyzny Dantego, naznaczonej stróżkami atramentu, który zakrzepł ponad sto lat temu...

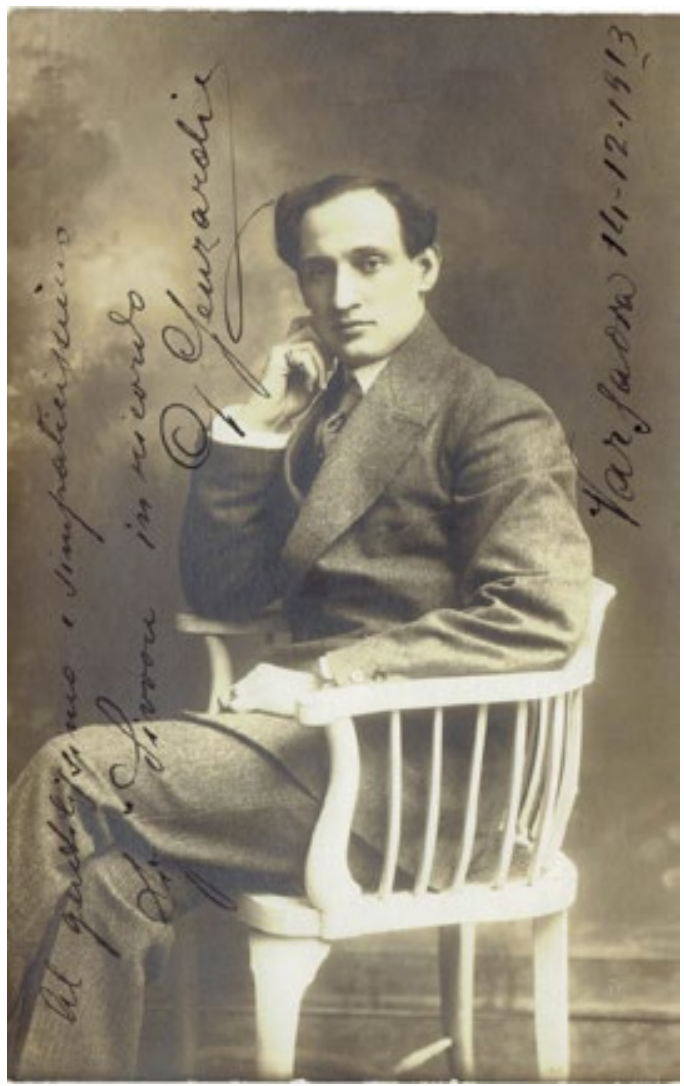

Fotografia nr 2 
Roland Barthes uznał, że każda fotografia zawiera w sobie coś strasznego - coś, co (chyba nie bez inspiracji freudowskich) określał mianem ,powrotu umarłego” lub ,władczym znakiem naszej przyszłej śmierci”3. W okolicznościach, w których pisał La chambre claire (1980), wybitny francuski humanista, pogrążony w bolesnej żałobie po śmierci matki, raczej nie mógł docenić faktu, iż fotografie bywają (a może niekiedy dopiero się stają) sardoniczną czy po prostu błazeńską kpiną z przemijania. Właśnie to - poza wrażeniem sobowtórowego powtórzenia - uderza mnie w zamieszczonym na wstępie zdjęciu grupy rozbawionych przyjaciół, które trzymam w dłoni, po którego nadwątlonej, chropowatej powierzchni wodzę palcami...

- No bo z czego natrząsają się ci panowie, stłoczeni na niegrubej tekturce, obwieszczającej całą swą istotą kruchość materii? Czyż nie śmieją się w twarz śmierci - i to z wielką satysfakcją?

Nie jestem, a nawet nie pragnę być poetką; do tego trzeba by mieć poczucie misji i wielką odwagę, zwłaszcza teraz, już po Leśmianie. Raczej mogę uważać się za wyjątek, bo nawet na fali młodocianych porywów serca nie robiłam zakusów na mowę wiązaną. Jednak w moim przypadku wielkie upodobanie do starych fotografii (zupełnie nieoczekiwanie dla mnie samej) zespoliło się z doświadczeniem niewyrażalności, które dopomina się o jakąś formę artykulacji. Zachłannie czytuję książki o dawnych fotografiach, zwłaszcza te przynoszące ich reprodukcje, jak tom esejów About Looking $(1980)^{4}$ Johna Bergera, Dno oka (2010) oraz Odbicie (2015) Wojciecha Nowickiego czy Fotoplastikon (2009) Jacka Dehnela - zbiór miniatur prozatorskich, do którego powracam zawsze z satysfakcją. Ale gdy sama natrafiam na to coś w starych zdjęciach, rodzi się we mnie potrzeba wyrażenia

${ }^{3}$ R. Barthes, Światło obrazu, op. cit., s. 21 i 172.

${ }^{4}$ J. Berger, O patrzeniu, tłum. S. Sikora, Warszawa 1999. 
emocji, przeczuć czy po prostu wyobrażeń przez nie wywołanych w języku „bardziej osobnym”, w formie w większym jeszcze stopniu intuicyjnej. Tym, i tylko tym chcą być poniższe wersy...

\author{
TWARZĄ W TWARZ \\ właśnie że tak \\ twarze zakrzepłe w przebrzmiałym oddechu \\ próchnieją od brody do skroni \\ chichocząc \\ w nieskończoność \\ jeszcze nie nasze \\ maski na nagich kościach \\ bezimienne \\ próżne już lęków uniesień \\ powalane wybroczynami istnienia \\ Może i są absurdalne \\ ale \\ nie spadają \\ $\mathrm{z}$ miny \\ śmieją się w twarz \\ nieistnieniu \\ tak uporczywie
}


INTRUZ W STARYM ATELIER...

II.

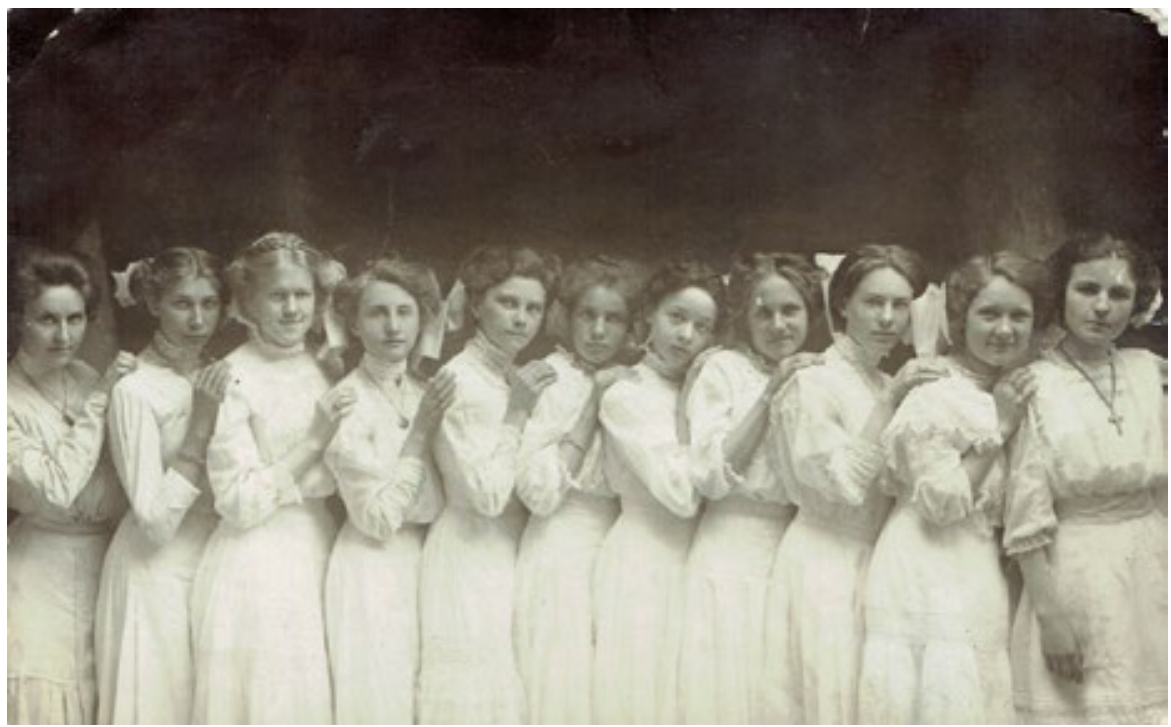

Fotografia nr 3

ILUMINACJA (1)

zastęp aniołów wtulonych w objęcia Nocy 


\section{III.}

W szkicu zatytułowanym Heroizm widzenia Susan Sontag formułuje następującą opinię: ,Siła zdjęcia polega na tym, że umożliwia spokojne przyjrzenie się chwilom, które upływ czasu zazwyczaj szybko zastępuje innymi. To zamrażanie czasu - bezczelne, dotkliwe stasis każdego zdjęcia - stworzyło

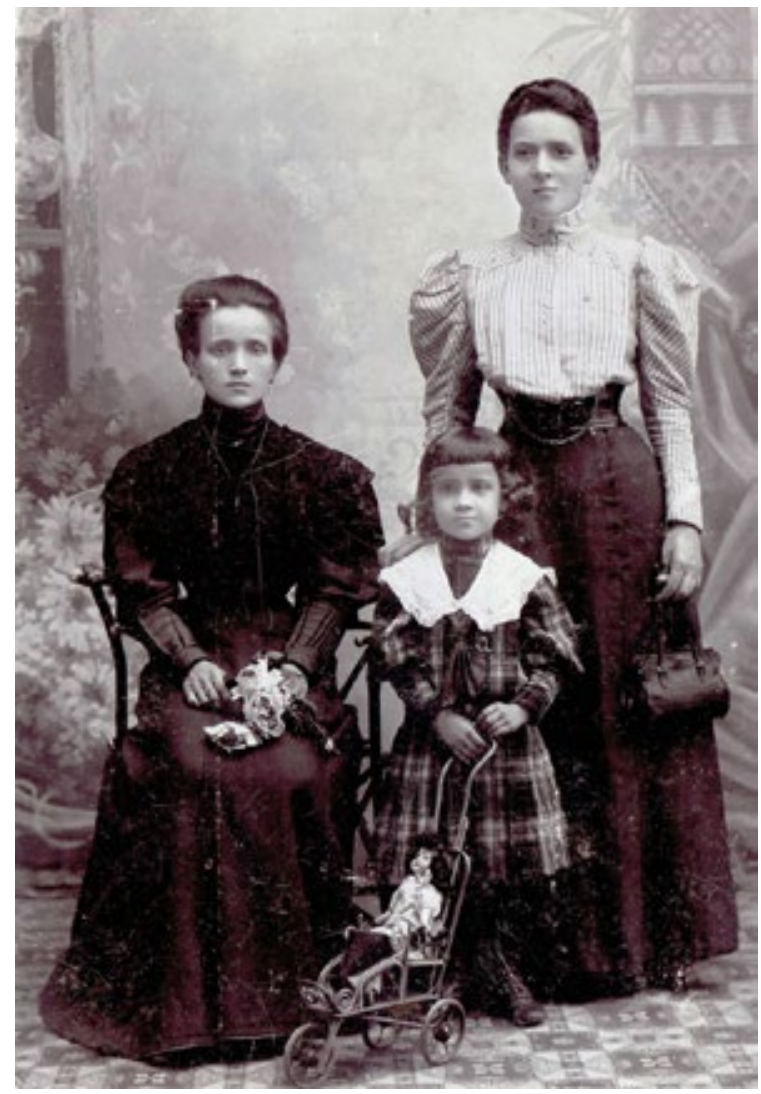

Fotografia $\mathrm{nr} 4$ 
nowe, bardziej pojemne kanony piękna. Ale prawdy, uwieczniane każda w osobnej chwili, choćby niewiadomo jak ważne czy przełomowe, bardzo niewiele mają wspólnego z potrzebą zrozumienia"5. Amerykańska intelektualistka dochodzi do wniosku, że estetyczne walory aparatu (właściwa mu zdolność do przekształcania rzeczywistości w coś pięknego) wypływają z jego „względnej słabości jako narzędzia przekazywania prawdy”.

Generalnie rzecz biorąc, trzeba będzie uznać słuszność wywodu Sontag, jeśli w fotografowaniu pragniemy dopatrzeć się aktu poznawczego pojętego jako dzieło świadomej inteligencji. Przytoczone wnioski okażą się jednak niechybnie dyskusyjne czy wręcz wątpliwe, gdy zdjęcie potraktujemy jako medium intuicyjnego, przedintelektualnego kontaktu z rzeczywistością. W kontakcie takim, jeśli odbywa się za pośrednictwem aparatu fotograficznego, na pierwszy plan wysuwa się doświadczenie czasowego wymiaru istnienia. Sądzę, że można by nawet spojrzeć na Fotografię jako na taką for m ę „chwytu udziwnienia", która z zasady wzmacnia odczuc i e c zasu (zarówno czasu ,przedstawionego”, jak i, w pewnym przynajmniej stopniu, aktualnie przeżywanego w akcie odbioru), w y zwa lając go z automatyzmu percepcji ${ }^{7}$. Czy nie na tym przede wszystkim polega wyjątkowa predyspozycja fotografii do artystyczności? Czyż nie w tym zarazem tkwi tajemnica jej egzystencjalnego ciężaru?

Jak zahipnotyzowana wpatruję się w zwyczajną (na pierwszy rzut oka) fotografię: przystojne młode kobiety $\mathrm{z}$ wdziękiem właściwym belle époque pozują ze śliczną ciemnowłosą dziewczynką w kraciastej sukieneczce, zwieńczonej białym kołnierzem, i w sznurowanych bucikach; w centrum obrazu dwie wspaniale wyrzeźbione talie, zdradzające oczom malkontentów okrucieństwo dziewiętnastowiecznych gorsetów, w tle - namalowana

${ }^{5}$ S. Sontag, O fotografii, thum. S. Magala, Kraków 2009, s. 122.

${ }^{6}$ Tamże.

${ }^{7}$ Por. W. Szkłowski, Sztuka jako chwyt, tłum. R. Łużny, [w:] Teoria badań literackich za granica. Antologia, red. S. Skwarczyńska, Kraków 1986, t. 2, cz. 3, s. 10-28. 
jedynie, lecz przecież urokliwa sceneria chyba egzotycznego ogrodu, w którym w roli trawy obsadzono regularne wzory dywanu. Żadnych dat, dedykacji, śladów atramentu, jedynie na odwrocie zakrzepłe w rogach plamy kleju, z pozostałościami brunatnej tektury - bezsprzecznie najbardziej namacalne wspomnienia po rodzinnym albumie.

Najpierw próbuję odgadnąć, kto jest matką dziewczynki, szukam podobieństwa rysów w trzech twarzach, zamiast niego rzuca mi się w oczy coś, co z początku umknęło mojej uwadze: buzia małej kobietki, która z wdziękiem trzyma za uchwyt zabawkowego wózeczka, jest nieco rozmyta - czyż to subtelny sygnał oporu ze strony nagle zamrożonego ruchu? Chwilę potem patrzę już tylko na dolne partie zdjęcia, by skupić się na detalu, który - jak rzekłby Barthes - „,szczególnie mnie nakłuwa”, odkrywam punctum tej fotografii ${ }^{8}$. Szczegółem tym jest lalka o porcelanowym obliczu i sylwetce wyschniętej miniaturowej mumii - przedmiot, który (zwłaszcza w warunkach szczególnej intensyfikacji napięć związanych z czasem i egzystencjalnymi determinantami bytu ludzkiego) niesie w sobie silny ładunek emocjonalny i wyobrażeniowy. Jego potencjał związany jest z takimi antytezami: „żywe - nieżywe, ożywające - zastygające, obdarzone

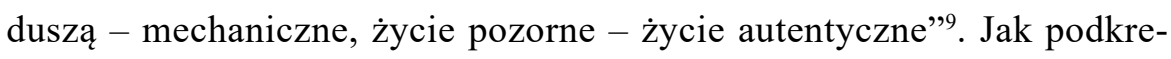
ślał przed laty Jurij Łotman, lalka poprzez podobieństwo do człowieka zalicza się do niezwykle istotnych przedmiotów kultury i sztuki, a z jej pojęciem wiązać należy szczególną aktywność znaczeń metaforycznych ${ }^{10}$. Rozpoznania rosyjskiego semiotyka rzucają snop światła na fakt, że nie potrafię już patrzeć na to porysowane zdjęcie jak na zwyczajną pamiątkę, zamiast tego dumam nad złowróżbną więzią, która zespala czarnulkę

${ }^{8}$ R. Barthes, op. cit., s. 78-79.

${ }^{9}$ Por. J. Łotman, Lalki w systemie kultury, thum. P. Ustrzykowski, „Teksty” 1978, nr 6, s. 52.

${ }^{10}$ Tamże, s. 46-47. 
w kraciastym ubranku z jej ulubioną kukiełką, w mej wyobraźni bardzo oddaloną od „przytulnego świata dzieciństwa"11.

Rzeczywiście wszystkie zdjęcia skłonni jesteśmy prędzej czy później postrzegać jako skamienieliny minionych chwil, jednak tylko niektóre z nich zdają się ów petryfikujący ,gest” immamentnie tematyzować, przez co rozumiem sytuację, gdy ukazany przedmiot, jak i sposób przedstawienia wywołują - metafizyczną w swej istocie - refleksję nad istotą czasu oraz zdziwienie wrażeniem doświadczania jego swoistej nieciągłości ${ }^{12}$. Takie doznanie dotyka nas chyba najsilniej, gdy zdjęcia nadgryzione zębem czasu sugestywnie prezentują młodość przed progiem pełnoletniości, a zwłaszcza fizjonomie dzieci - fotografie tego rodzaju wręcz obsesyjnie przywodzą z du mi e wającą za każdym razem myśl o nieuchronnej (już zaszłej) śmierci istot, których oblicza uwieczniają. Jeśli chodzi o wizerunki postaci ludzkich, opisana reakcja narzuca się z potężną mocą oczywistości, jednak jej główne źródło bije raczej w nas samych, a nie tyle w szczególnych ujęciach przedstawień: jest ona przede wszystkim pochodną naszej wiedzy o świecie i naturalnego wyostrzenia egzystencjalnego, które znamionuje wrażliwość człowieka, a które fotografia nader skutecznie ,przekształca w przedmiot czułego rozmarzenia” (jak to ujmuje Sontag), uwzniośla i sentymentalizuje ${ }^{13}$. Trzeba dodać, że w pewnym aspekcie pokrewne reakcje zdają się wywoływać

${ }^{11}$ Łotman zwraca uwagę na dwuznaczność mitu lalki: „,(..) w naszej świadomości kulturalnej utrwaliły się jakby dwie twarze lalki: jedna wabi w przytulny świat dzieciństwa, druga kojarzy się z pseudożyciem, martwym ruchem, śmiercią imitującą życie. Pierwsza twarz przegląda się w świecie folkloru, baśni, prymitywu, druga przywodzi na pamięć maszynową cywilizację, wyobcowanie, zjawisko sobowtóra" (tamże, s. 50).

${ }^{12}$ Mam tu na uwadze poczucie ,nieciągłości”, pojęte jako z gruntu subiektywne wrażenie nieprzystawalności czasowej świata przedstawionego fotografii względem naszego własnego, aktualnego (w momencie aktu percepcji) istnienia. Chodziłoby nie tyle o zdroworozsądkową świadomość dystansu czasowego w stosunku do przeszłości, co o jego imaginacyjną czy emocjonalną wykładnię.

${ }^{13}$ Por. S. Sontag, op. cit., s. 80-81. 
fotografie, które prezentują obrazy zdynamizowane, eksponując przy tym motywy postrzegane jako metonimie ruchu czy zmiany, na przykład pył podbity impetem rozpędzonych końskich kopyt, fale rozbryzgujące się w miliony kropel, od stu lat jakby zawieszone nad taflą wody, ,przerwany” w połowie gest itp.

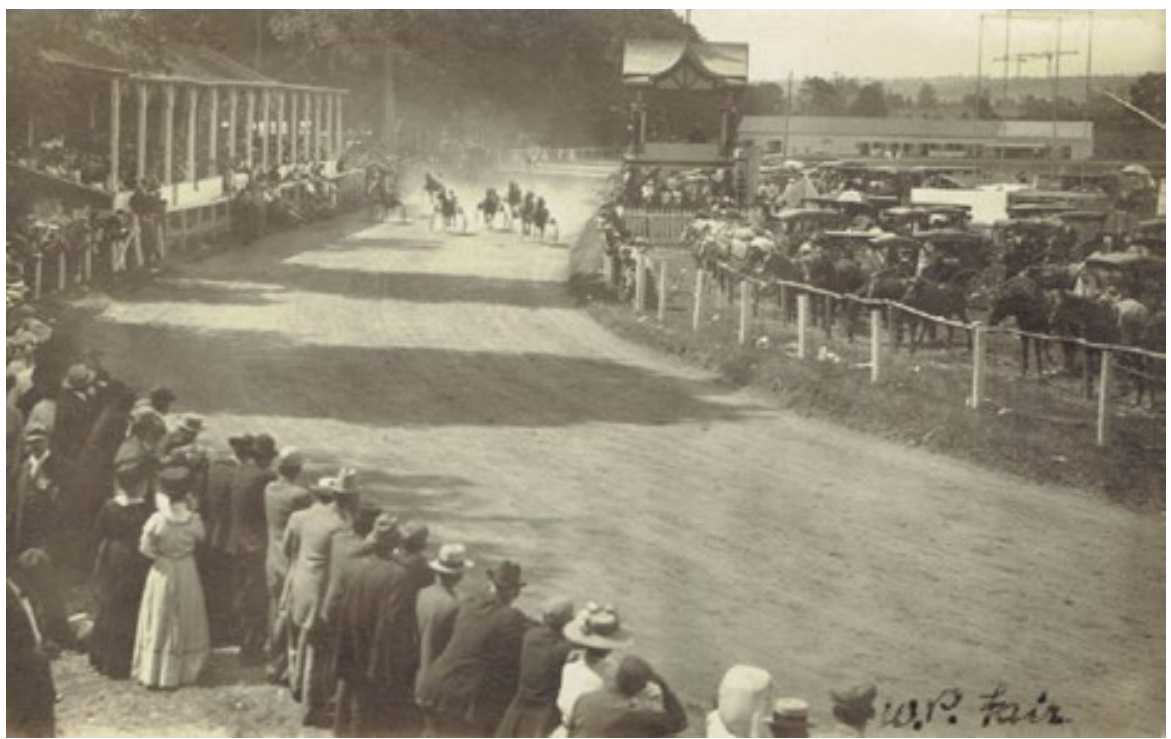

Fotografia nr 5 


\section{STARA FOTOGRAFIA}

w słońcu tamtej niedzieli

przepastnie minionej

widzę ich odwróconych

wciąż stoją

niezłomnie

a przed oczyma ich rosną fakty

dyskretnie podglądam jak

z kwiatem w kapeluszu

$\mathrm{z}$ monoklem w kieszeni

milkną w natężeniu

do bólu prężą palce

w pyle końskich kopyt

co wzbiera gwałtownie

rozluźniają kołnierzyk

wstrzymują szybki oddech

przecieram lupę

ze zdziwienia

że nie zakurzy się

nigdy 


\section{IV.}

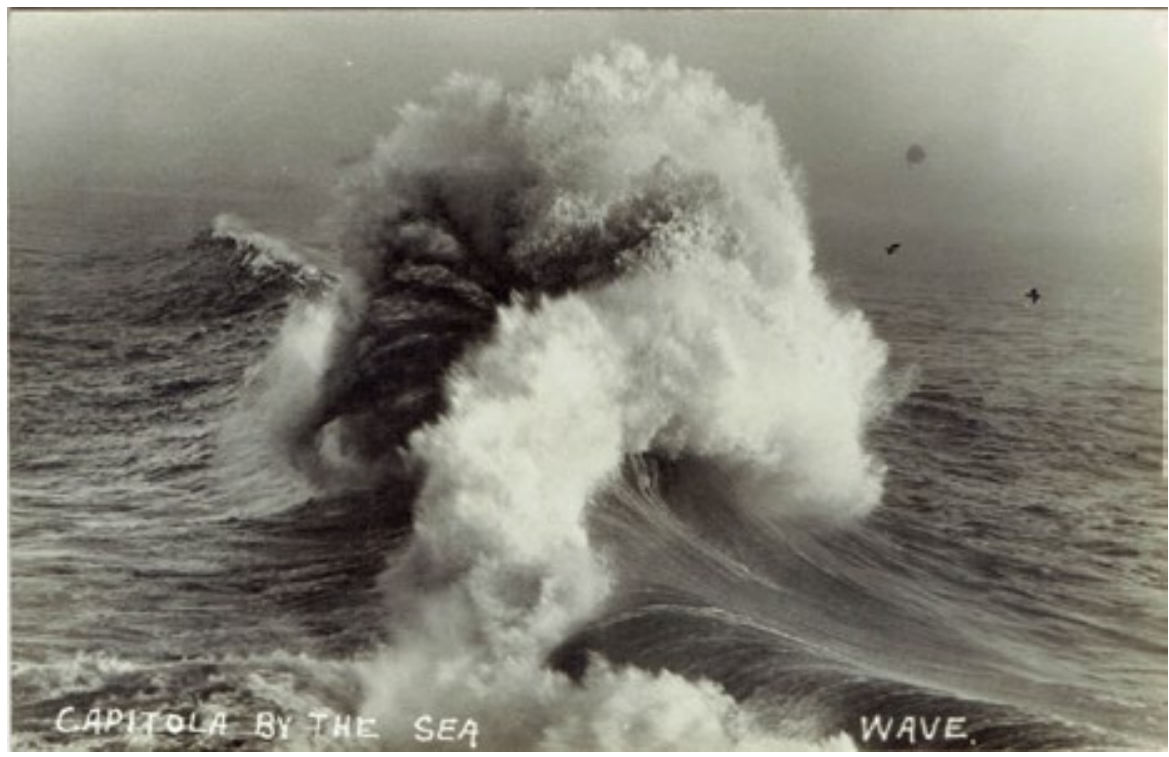

Fotografia nr 6

\section{ILUMINACJA (2)}

upadek kobiety-Ikara 


\section{V.}

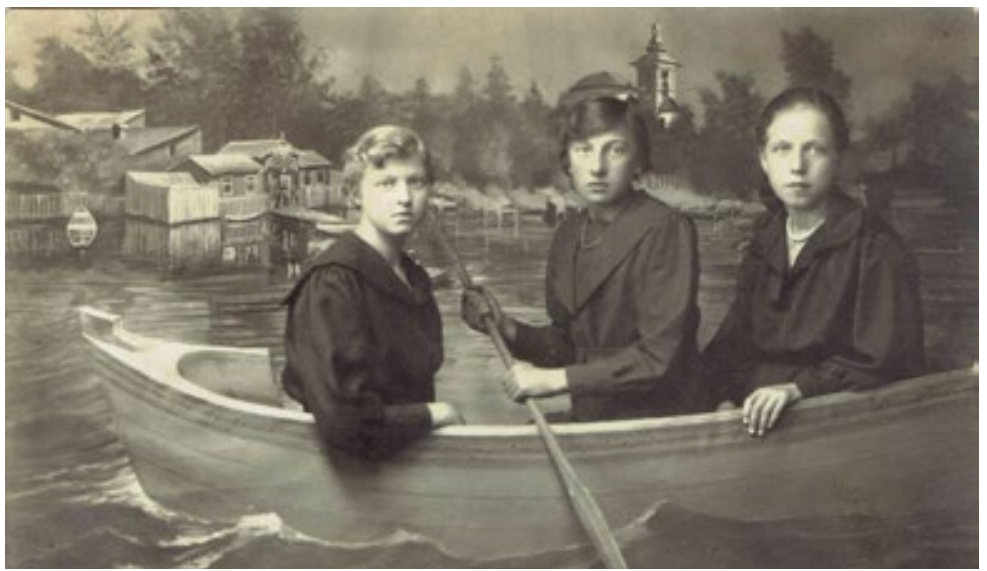

Fotografia $\mathrm{nr} 7$

Pierwszą rzeczą, która przychodzi mi na myśl, gdy patrzę na tę fotografię, jest Zaproszenie na egzekucję Władimira Nabokova - powieść cienka, lecz wielka (co zresztą dość częste w przypadku niegrubych książek). To skojarzenie ma charakter całkowicie arbitralny i nie widzę powodu, aby je w tym miejscu uzasadniać, ale ufam, że wielbiciele twórczości wybitnego Rosjanina nie poczują się nim całkowicie zdezorientowani. Zdecydowałam się przywołać utwór Nabokova, by podkreślić kwestię mającą, moim zdaniem, zasadnicze znaczenie z punktu widzenia estetyki wyobraźni oraz psychologii odbioru różnorodnych tekstów kultury, w tym (nieoczekiwanie?) i fotografii - tych zwłaszcza, które konfrontują nas z zasadniczo obcym kontekstem czasowo-przestrzennym ${ }^{14}$. A mianowicie, wydaje się, że w takiej sytuacji umysł odbiorcy (przynajmniej tego obytego w artystycznym kanonie

${ }^{14}$ Postrzegam tę zależność poprzez pryzmat formalistycznej koncepcji uniezwyklenia, defamiliaryzacji. Warto przypomnieć, że słownikowymi przykładami wykorzystania tego chwytu w literaturze są: ukazanie jakiejś banalnej sytuacji z punktu widzenia cudzoziemca, dziecka, psychopaty. 
kultury) wykazuje szczególną predylekcję do metaforycznej czy parabolicznej „lektury” zdjęcia, co w sposób naturalny przebiega poprzez myślowe wychylenie się ku przestrzeniom intertekstualnym.

Jak można przeczytać tę fotografię sprzed wieku, która przedstawia dziwnie zasępione nastolatki w dekoracjach zgoła nieadekwatnych do wyrazu ich twarzy?

\author{
TRZEBA PŁYNĄĆ \\ porę odpływu obwieszcza się \\ jak zawsze \\ szeptem
}

plusk mętnego nurtu

wije się falistą wstęgą pergaminu

oplata od niechcenia kibić samotnego wiosła

jedynej podpory

dla zbłąkanych dłoni zatrwożonych dziewic

w nim teraz cała otucha

gdy w konwulsjach drwiącego chichotu

runął już z płachty nieboskłonu

tekturowy księżyc

co rozświetlał otchłanie

wątłą nadzieją przejścia

trzeba wytrwale śledzić linię horyzontu

na drugim planie stosownie wybrzuszoną

i patrząc głęboko przed siebie

dryfować bez lęku

- cóż bowiem z tego że łódź krucha

skoro przystań

na wyciągnięcie ręki? 
VI.

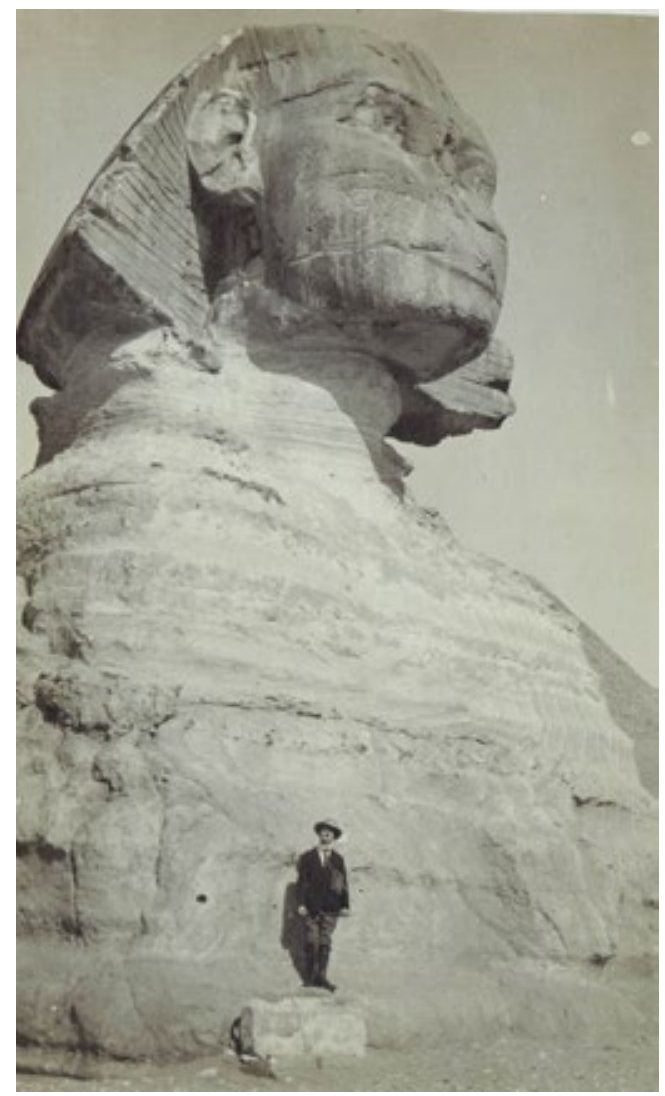

Fotografia nr 8

A inspiracje tej przekornej ekfrazy chyba mogę pominąć milczeniem...

\section{PROSTA ODPOWIEDŹ}

- Człowiek?...

...to twórca nawiedzony i ślepy,

co poznać swego dzieła nie może, więc złorzeczy mu - 


\section{VII.}

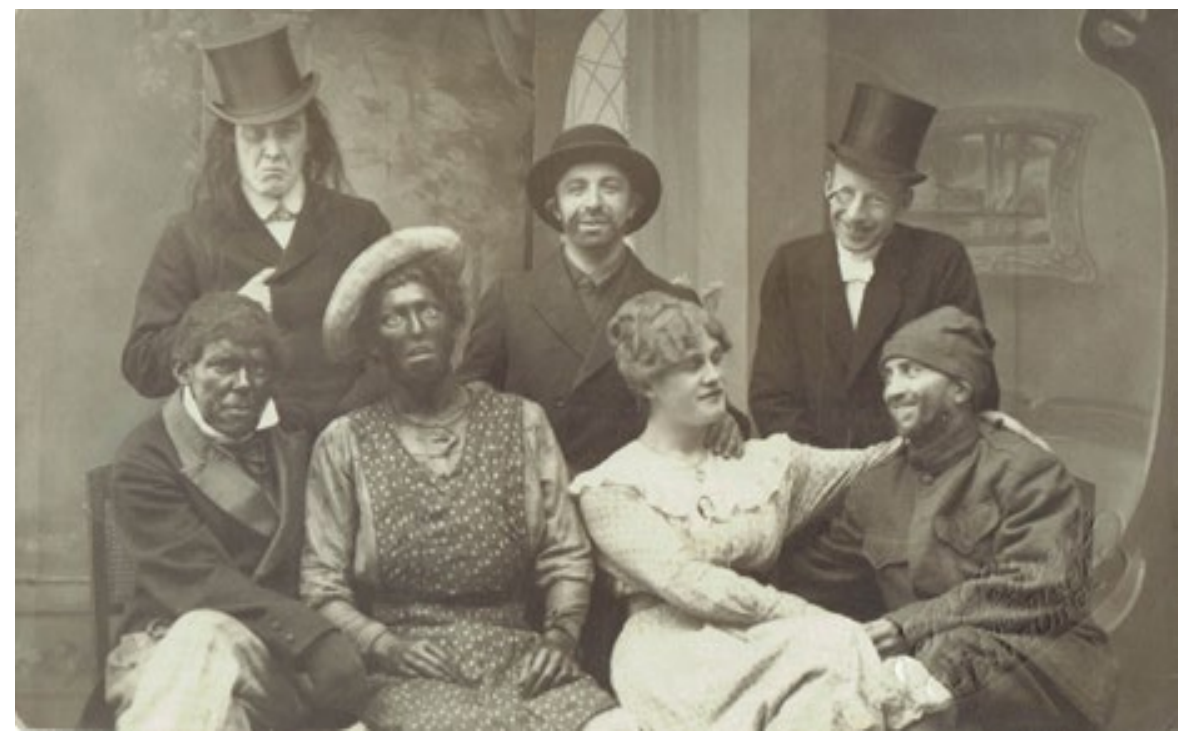

Fotografia nr 9

\section{ILUMINACJA (3)}

dworuje sobie ze mnie trupa zaświatowych szyderców 
* Niniejszy szkic nie do końca jest tekstem o charakterze naukowym. W moim autorskim zamyśle stanowi on raczej swoisty esej naukowy - taki mianowicie, który czyni swą dominantą (kompozycyjną, myślową, wyobraźniową, afektywną) stare fotografie. O doniosłej, niepodrzędnej roli fotografii w jego obrębie świadczy nade wszystko fakt, że każdy wyodrębniony wokół konkretnego zdjęcia fragment wywodu osiąga kulminację przebiegu znaczeniowego w p o e ty cki e j e k frazi e poświ ęconej danem u zdjęci u, ekfraza ta pozostaje zaś w bezpośrednim związku, tematycznym i znaczeniowym, z partiami odwołującymi się w mniejszym bądź większym stopniu - do dyskursu naukowego. („Niezbędność” fotografii $\mathrm{w}$ tej $\mathrm{z}$ gruntu heterogenicznej rozprawie bodaj najdobitniej uwidacznia się w paragrafach opatrzonych tytułem Iluminacja, których wymowa w zupełności opiera się na transsemiotycznym przepływie znaczeń; usunięcie zdjęć z tych paragrafów uczyniłoby je wręcz wypowiedziami pozbawionymi sensu, a już na pewno - pozbawionymi t y ch w w a śn i e znaczeń.) W moim przeświadczeniu niniejszy szkic można zatem w sposób umotywowany określić mianem „,fotoeseju”, przy czym upatrywałabym jego niekonwencjonalnego charakteru w zespoleniu elementów naukowości i - immanentnie motywowanej-poetyckości. Sądzę, że gatunek fotoeseju stwarza szanse na ożywienie myśli humanistycznej: np. na polu badań tekstów kultury (zwłaszcza artystycznych lub jako takie interpretowanych) daje okazję do otwarcia (quasi)naukowego dyskursu na transsemiotyczną i transmedialną sferę znaczeniową oraz związane z nią rozpoznania, dopuszcza m.in. uwzględnienie myśli, wyobrażeń i przeżyć związanych z ,intertekstualnością fakultatywną” (termin Ryszarda Nycza), wreszcie uwalnia autorów od „przymusu" odwoływania się do prac tych badaczy analogicznych zagadnień, którzy niekoniecznie byli dla nich realną inspiracją, a których pominięcie „w normalnym trybie” uznano by za defekt rozprawy. Biorąc pod uwagę ostatnią kwestię, odsyłam wszystkich czytelników, którzy są zainteresowani bardziej systematycznym wywodem na temat form wizualno-tekstowych oraz bogatą bibliografią na ich temat, do obszernej książki Marianny Michałowskiej Foto-teksty. Zwiazki fotografii z narracja, Wydawnictwo Naukowe UAM, Poznań 2012. Zob. także publikację Marty Koszowy, W poszukiwaniu rzeczywistości. Mediacyjna rola fotografii we wspótczesnej prozie polskiej, Universitas, Kraków 2013.

\footnotetext{
Wszystkie fotografie pochodzą z prywatnej kolekcji Autorki niniejszego szkicu: $\mathrm{nr} 1$ - fotografia nabyta na warszawskim pchlim targu, niedatowana.

$\mathrm{nr} 2$ - fotografia nabyta na warszawskim pchlim targu, $1913 \mathrm{r}$.

$\mathrm{nr} 3$ - fotografia nabyta przez Internet w Stanach Zjednoczonych, $1910 \mathrm{r}$.

$\mathrm{nr} 4$ - fotografia nabyta na warszawskim pchlim targu, niedatowana.

nr 5 - fotografia nabyta przez Internet w Stanach Zjednoczonych, 1912 r.

nr 6 - fotografia nabyta przez Internet w Stanach Zjednoczonych, niedatowana.

$\mathrm{nr} 7$ - fotografia nabyta na warszawskim pchlim targu, $1921 \mathrm{r}$.

$\mathrm{nr} 8$ - fotografia nabyta przez Internet w Stanach Zjednoczonych, niedatowana.

nr 9 - fotografia nabyta przez Internet w Stanach Zjednoczonych, niedatowana.
} 


\section{Nowości Wydawnictwa UKSW}

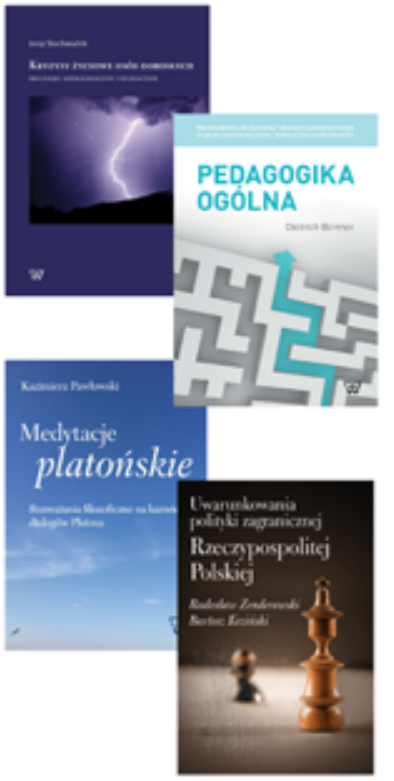

- Jerzy Stochmiałek, Kryzysy życiowe osób dorosłych

- Dietrich Benner, Pedagogika ogólna

- Kazimierz Pawłowski, Medytacje platońskie. Rozważania filozoficzne na kanwie dialogów Platona

- Bartosz Koziński, Radosław Zenderowski, Uwarunkowania polityki zagranicznej Rzeczypospolitej Polskiej

Więcej informacji na stronie: www.wydawnictwo.uksw.edu.pl 